\title{
Ethiopian Foreign Policy Under Military and EPRDF Regimes: Changes and Continuities
}

\author{
Negera Gudeta Adula \\ Department of Civics and Ethical Studies, College of Social Sciences and Humanities, Mettu University, Mettu, Ethiopia \\ Email address: \\ negera2017gudeta@gmail.com \\ To cite this article: \\ Negera Gudeta Adula. Ethiopian Foreign Policy Under Military and EPRDF Regimes: Changes and Continuities. Journal of Political \\ Science and International Relations. Vol. 2, No. 1, 2018, pp. 25-31. doi: 10.11648/j.jpsir.20190201.14
}

Received: October 29, 2018; Accepted: November 27, 2018; Published: June 20, 2019

\begin{abstract}
This paper attempted to examines changes and continuities of Ethiopian foreign policy under the military and EPRDF regimes. Accordingly, the paper argues that there are changes and continuties in Ethiopian foreign policymaking and executions under military and EPRDF regimes. The study used secondary source of data; collected from books, journal articles, published and unpublished materials, governmental and non-governmental organization reports and remarks, magazines and web sources. To substantiate and supplement the secondary data, the paper also used primary data collected through key informant interview. Given the data gathered are qualitative, the study employed qualitative data analysis techniques. The finding of the study revealed that the demise of military regime brought not merely change in terms of foreign policy making and execution but also brought shift in foreign policy approach and orientation of the country from out-ward looking foreign policy to in-ward looking foreign. Despite, a shift in orientation and style of foreign policy, domestic factors, and external factors remain the defining factors of Ethiopian foreign policy under both military and EPRDF regimes.
\end{abstract}

Keywords: Ethiopia, Foreign Policy, Military Regime, EPRDF Regime, Changes and Continuities

\section{Introduction}

Ethiopia assumed as the state of millennia history. However, the formation of modern Ethiopian empire traced back to mid of the $19^{\text {th }}$ Century [24] after termination of era of zemene mesafint (Era of princes or regional lords) and the coming of RasKasa [21] who traced his lineage to the house of David and King Solomon, succeeded in consolidating his rule over the Abyssinian core from which modern Ethiopia would flower and who sought the assistance of European states to modernize to the country and defend the threat Egypt and Turk which were Muslim states.

The formation of modern Ethiopian empire ushered the foundation for genesis of the modern Ethiopia's foreign relations and foreign policy but initially it was dominated by state to state relations that marginalized the participation of none state actors though the foreign policy document of the country was not adopted till 1996 when the official document of Ethiopian foreign policy was adopted by EPRDF government [13].

Ethiopia has a long diplomatic history and extensive experience in foreign relations. Since theformation of modern
Ethiopian empire, different regimes have been using foreign policy and foreign relations as the best means to modernize the country, maintain sovereignty and defending the national integrity of the country. However, there always changes and continuities of Ethiopian foreign policy under different regimes though the central purpose of Ethiopia's foreign policy has remained the same.

Thus, the objective of this study is to examine the changes and continuities of Ethiopian foreign policy under military and EPRDF regimes. In terms of methodology, the study employed the qualitative research methodology and narrative research design was employed to achieve the objective of the study. Accordingly, the study used a secondary source of data; collected from books, journal articles, published and unpublished materials and archives. To substantiate the secondary data, primary data was also collected via key informant interview from key actors and pertinent experts. Given the data gathered are qualitative; the study also employed the qualitative technique of data analysis. 


\section{The Foreign Policy of Military Regime}

Military regime held the throne in 1974, after topple of the imperial regime. In the $1960 \mathrm{~s}$, armed conflicts arose in different parts of the country and university students nurtured the ideas which provided the ideological ammunition for resistance against the imperial regime and which aggravated the uprising in different provinces of the country which in turn paved the way for the demise of the imperial regime [24].

The occasion was again accelerated by different factors that initiate the teacher, student, farmer, civil servant to revolt against the imperial regime like shortage of water, food, taxation problem, unemployment, delay of salary payment and other social services problem throughout the corner of the country which finally amounted to the downfall of Imperial regime [3]. Ethiopia foreign policy and foreign relations during military regime was primarily rooted in "Westphalia principles with its emphasis on the security, territorial integrity and sovereignty of the Ethiopian state [6].

The foreign policy of the country also remains on the hand the Mengistu Hailemariam who was the chairman of the military regime and chief of armed force. At the beginning the military regime's foreign policy remain the same with the foreign policy of Imperial regime which was western centric and highly securitized approach especially with European Countries and USA but later on the foreign policy of Ethiopia was shifted from West (European countries and USA) to East(Soviet Union and Warsaw pacts) due the reduction USA support to Ethiopia due to military regime poor human right records. The Ethiopian foreign policy during military regime was also based on out-ward looking approach which externalized almost all the country's problems by focusing on building military defense capabilities against the 'historical enemies of Ethiopia.

The formulation of Ethiopian foreign policy under the military regime was influenced by the Marxist-Leninist ideology and Marxist concepts of society and the alignment of forces even though the essence of foreign policy is similar to that of his predecessors but unlike its predecessors the military regime's foreign relations and policy solely depend on the Soviet Union since the military regime consider the USSR as the natural ally of Ethiopia [2]. Beside this, Ethiopian foreign policy under the military regime also an ideology based (socialism) and the foreign policy of orientation of the regime was also outside-in approach (siege mentality approach) which was all about externalizing the problem of the country especially like his predecessors he considered the neighboring states of Ethiopia as historical enemy of the country and personal diplomacy was also what characterized the foreign policy of the country during military regime [1].

Like to that of other country, the making and execution of Ethiopian foreign policy during military regimes was determined by both internal and external political development and factors such historical legacy, the level of economic development, cold war, political dynamism in the horn Africa and the norms of the international system.

\subsection{Economic Development and the Nature of Political Development}

It is no doubt that Ethiopia is one the world poorest and economically backward countries during military regime due to imbalanced economy and inadequate socio-economic environment, though military regime nationalize the means of production and distribution and conduct different reform programs such as associating the peasant(collectivization), resettlement and state farming. The regime faced economic crisis due to both human made and natural factors such as drought, civil war which in turn amounted to difficulties and economic failure [23]. The nature of the political system during military regime was also characterized by the absence of unity and cohesiveness due to the advent of historical attempt to impose a single set of values on a multi-ethnic, multi-confessional, polyglot population which in fact leads to political instability. Despite the prevalence of initial promise of military regime to ensure popular participation, equality of all people and respect of people's fundamental rights but the reality on the ground is different because of the nature of political system was dictatorial and believe in the slogan of Ethiopia first and historical legacy of Haile Selassie's political system. Thus, it was these domestic political and political realities that determined the style, the approach and objectives of Ethiopia's foreign policy during military regime.

\subsection{Historical Legacy and Military Capability}

The historical worry has also dominated the perception and attitudes of all Ethiopian regimes; suspicion of their neighbors' rooted in the memory of past confrontations. The Christian ruling classes of Ethiopia have long been convinced that 'Arabs' and 'Muslims' can never be reconciled with their nation's interests (national interest of Ethiopia). This historical tragedy made the military regime to develop outward, rigid and reactive foreign policy which intended to against the interest of neighboring Arab states. The foreign policy strategies developed by military regime include expanding divisions between Arab states, to pit Africans against Arabs, making arrangements with those in a position to influence Arabs and to search for a powerful patron.

The historical legacy and worry was clearly expressed by emperor Tewodross II letter to Queen Victoria of England which state that "Ethiopia is the only Christian state in the Horn of Africa and Red sea which surrounded by Muslim states which are the enemy of Ethiopia since they intended to create one Muslim state in the Horn of Africa". So, it was this historical legacy which pushed the military regime to develop anti-Arabian state foreign policy and strongly rely on USSR, India, Yugoslavia, Italy and other western European state to forge against Arab states in Organization of Africa Union. In a nutshell, it was this siege mentality approach that also forced the military regime to militarize its foreign policy and diplomacy, and expands its military defense capabilities in the face of 'historical external enemies.

Thus, maintaining territorial integrity and national 
sovereignty equality of Ethiopia was the primary of objective of Ethiopian foreign policy since the formation of modern Ethiopian empire and again during the reign of the military regime which is fact realized based on the national or military capacity of the country. To this end, the military regime allocates the $60 \%$ ) sixty percent of the annual budget for the military sector in addition to aid which received from the Soviet Union. Ethiopia ranked first in terms of allocating a large amount of money from the annual budget for armed force and again in terms quantity of armed force which resulted from the absence of durable peace in Horn of Africa and Ethiopia. Despite this, the armed force of Ethiopia under military regime was not well-trained and this resulted in the defeat of the armed forces by ethnic based internal movements like Eritrean People Liberation Front, Tigray People Liberation Front, Oromo Liberation Front and other insurgent movements. Therefore, historical legacies and domestic military capability determine Ethiopian foreign policy and its response to these domestic threats remains the main determinant of Ethiopia's foreign policy under military regime.

\subsection{Leadership and Image the Regime}

President's idiosyncrasies was the determinants of Ethiopian foreign policy and foreign relations under military regime, under the military regime, all political power was concentrated under the strong hand of Mengistu Hailemariam who was the Secretary-General of the Worker Party of Ethiopia and the President of the People's Democratic Republic of Ethiopia and Commander-in-Chief of the Armed Force. He has controlled the all political activities of the regime and the foreign policy of the country was approved by him and the outcome of Ethiopian foreign policy was reflection of the President's idiosyncrasies, major decisions in foreign policy have taken place without sufficient thought about its consequence and implication for Ethiopia. Therefore, this monopoly of authority adversely affects the predictability and clarity of foreign policy and makes its systematic formulation and execution difficult [2].

\subsection{Regional and Global Political System}

Ethiopia found at the epicenter of Hornof Africa. The political condition and political atmosphere found in the Horn Africa affects and determine the foreign policy of Ethiopia since the reign of emperor Tewodros II to even today due to the spillover effects of what happened other Horn of Africa states. Ethiopian foreign policy always affected by the political situation found in the Horn of Africa region.

Thus, it political environment and political culture in the Horn of Africa determined Ethiopian foreign policy under military regime because during the then time officials of the regime and president Mengistu himself believe that Ethiopia is surrounded by several unfriendly states, who's inhabitants share more differences than similarities, and whose relationships have largely been characterized by mutual suspicion and violent hostility. This made the regime to understand that, the major security threat of Ethiopia is an external threat since the foreign policy approach and orientation of regime was an outside-in approach [4].

Beside this, Ethiopia is the independent state in the Horn of Africa and this resulted in the conduct of boundary demarcation between Ethiopian and European powers (Britain, France, and Italy) and it was this boundary demarcation which incorporated Ogaden and surrounding area as part of Ethiopian empire especially during the reign of emperor Menelik II and again Eretria which was Italy colony was also federated with Ethiopia in 1952 as a result of UN resolution of $390(\mathrm{v})$. These two provinces were the major security threats of Ethiopia during the military regime and determine Ethiopian foreign policy and relations during the military regime and they were the catalyst for relationship with neighboring states because of the independent Somalia and Eritrea was not interested in the demarcated territory by colonial powers and that was what leads to the 1977 Ethiosomali war and the raise Eritrean People Liberation Front and other movements to against the regime [15]. Generally, Ethiopia is the only non-Arab and officially non-Muslim state in the Red Sea region, and because of its proximity to the Middle East, the oil-rich Persian Gulf, and the militarily important Indian Ocean, it continues to attract the attention not only of the two superpowers, but also Israel and various Arab governments, as well as Western Europe. Thus, due to the geostrategic nature of the country and its epicenter to all Horn of African states the Ethiopian foreign policy was affected by the political dynamism in the Horn of Africa.

The reign of the military regime (1974-1991) was also era of cold war and bipolar system which determined the foreign policy of nation states across the world. Thus, the same logic applies on the foreign policy of Ethiopia under the military regime because the milestone of Ethiopian foreign policy during the then time was making USSR and another socialist states the natural ally of the country. The near total dependence on the leaders in Moscow and their Warsaw Pact allies for military and logistical support during the war with Somalia and in the Eritrean conflict, several other factors has facilitated the consolidation of this new special relationship. The Soviet Union and its allies were thus exerted immense influence in both the domestic and foreign policy of Ethiopia and this made Ethiopia play central role Ethiopia in the informal network of Africa's Marxist regimes created during the late I970s and early1980s including Angola and Mozambique.

\section{Foreign Policy of Ethiopia Under EPRDF Regime}

The failures of the Marxist-Leninist regime to solve the national problems and national questions lead to the down fall of the military regime in 1991 and the regime was headed by the Ethiopian people Revolutionary Democratic Front(EPRDF) [14]. Mangistu dethroned in what eventually became known as the Ethiopian People's Revolutionary Democratic Front (EPRDF), a coalition of three regionally, 
and largely ethnically based guerrilla armies that included the Tigray People's Liberation Front (TPLF), Oromo Liberation Front (OLF), and the Eritrean People's Liberation Front (EPLF), secessionist movement dating back to 1961[20]. Since then, the approach and the orientation of Ethiopian foreign policy were redefined and the national interest of Ethiopia and the national security threat of Ethiopia also reidentified. Since then, EPRDF government redefined the countries national interest and national security threat. Accordingly, conflict, extreme and rampant poverty, and general backwardness depicted a as existential threats. The EPRDF believes this 'externalization' mindset poses the gravest of all existential threats to the nation, as old assimilations policies fail to govern ethnic or religious diversity effectively and The government has replaced an old, rigid and reactive strategy with a more flexible and, to a limited degree, proactive foreign policy [17].

Ethiopia's national security threats identified as internal vulnerabilities and problems, such as political and economic problems. The dethroning of the military regime brought not only shift in the foreign policy approach and orientation but also leads to adoption of the Foreign Policy and National Security Strategy document in 1996 for the first time in the history the country's foreign relations and the document redefined the countries national interest and redefined the major security threats to Ethiopia's survival [22].

The identified security threats by foreign policy and national security strategy are economic backwardness and poverty in which a large majority of the people exist, together with the understanding of the need for democracy and good governance and for the establishment of a democratic structure and government at all levels throughout the country. Without these, Ethiopia would be unable to survive as a country and its very existence would be in doubt and unless there is a speedy economic development, Ethiopia's survival as a nation is in danger. The approach and orientation of Ethiopian foreign policy were also changed from outside-in approach (Siege mentality) to in-ward looking approach this is to mean that the neighboring states are no more enemies of the country and no more perceived as the security threat of the country. Ensuring the fast-economic development and realization of democratization assumed as the alpha and omega for the survival of the country.

Moreover, the Ethiopian foreign policy under the EPRDF government is characterized by its effort to diversify its partner. Unlike its predecessors, the post-Cold War era Ethiopia's foreign policy and strategy has been characterized by the effort to diversify its partners with non-western powers such as China, India, Turkey, Brazil, Malaysia and the oil reach the Gulf States unlike the military regime which relied on the Soviet Union only and again area of engagement like foreign direct investment and addressing economic constraints through strategic trade negotiations, aid was also major dynamism in foreign policy of the country unlike the derg regime which emphasized the military sector alone. The rationale of the EPRDF's foreign policy and strategy document is to support the democratization process of the local politics and addressing economic constraints through economic diplomacy which facilitated by trade negotiations, aid and foreign direct investment [19]. Therefore, this implies that the emphasis of Ethiopian foreign policy under the EPRDF government is on economic diplomacy, there is a shift in foreign policy objective from hard power (military) to soft power (economy). However, though there are changes in foreign policy approach and style, the main objective of Ethiopian foreign policy remain the same i.e. maintaining national sovereignty and territorial integrity of the country has the remain the objective of Ethiopian foreign policy.

Even though there are changes in foreign policy approach and orientation under the EPRDF regime, domestic, regional, and global political environment remains the factors that determine and shape the nature, style, and objectives of the foreign policy of Ethiopia under the EPRDF regime. The EPRDF government redefined foreign policy objectives, national interest, and foreign policy orientation and approach of the country especially through adopting the Foreign Affairs and National Security Policy and Strategy in 1996 and revising it in 2002 which clearly identify the threats of national survival. Accordingly, economic backwardness, and nature of the political system (absence of democracy and good governance) portrayed as twin existential threats. Domestic problems such as grave democratic deficit; sectarian politics; corruption; the absence of constitutional accountability, judicial review and parliamentary oversight; the violation of human rights; and extreme poverty, all of which pose a threat to internal peace and security [17].

\subsection{Economic Backwardness and Poverty}

Since 1991, Ethiopia's national interests have been completely redefined to focus on the country's internal vulnerabilities and problems like poverty and economic backwardness. As clearly thrashouted in Ethiopian Foreign Affairs and National Security Policy and Strategy document of 2002 poverty and economic backwardness are two major threats to Ethiopia and its very survival. The document elucidated that the attainment of speedy economic development is fundamental to the survival of our country which finds itself in a state of abject poverty and backwardness [18]. Therefore, this implies that poverty and economic backwardness depicted as the major threat to statehood survival of the country and without the rapid economic development the viability of the country as statehood is doubt and this shift of foreign policy approach from outside-in approach to an inside-out approach lead to the change in foreign objective from hard power (military diplomacy) to soft power (economic diplomacy).

Thus, it was to this end why the EPRDF government emphasis economic diplomacy as a panacea to solve the poverty and economic backwardness by attracting foreign direct investors and enhancing export led industrialization. EPRDF government also believe that transforming and expanding Ethiopia's economy through agricultural sector, energy, and other sectors can realize rapid economic growth 
which can benefit all nations, nationalities, and peoples of Ethiopia and realize the very survival of the country-based Westphalia treaty-based statehood [5]. Moreover, the incumbent government also strongly believes that the national interest and security will be guaranteed if only rapid economic development is attained and this rapid economic development is critical for the protection of the national interests and security of the country [11].

Thus, poverty and economic backwardness is the major factor that determine the shape, the style, approach and orientation of Ethiopian foreign policy under the incumbent government since it is major threat to national interest country and it is a threat to perpetual survival of the country in addition to external influence and this was due refinement national interest of the county to democratization and economic development after the dethrone of military regime in 1991.

\subsection{Nature of Domestic Political System}

This is the other domestic determinant of Ethiopian foreign policy under an incumbent government which refers to the absence of democracy and good governance at the domestic level. This is clearly elucidated in Foreign Affairs and National Security Policy and Strategy of 2002; as lack of democracy and good governance is the source of our inability to work together in a spirit of tolerance and cooperation forged by a common belief in our national destiny [10].

Ethiopia completely redefined its national interest in post 1991 and gave a due emphasis for internal vulnerabilities which include the domestic political problem like absence of democracy and good governance which is in fact the prominent factor in determining state-society relationship and rapid attainment of democratization is key for viable survival of the state because absence of democracy and good governance is the major threat to Ethiopia's national interest and its very survival.

Moreover, the FANSPS document pointed out that establishing a democratic order in Ethiopia is the way to respect people and individual rights, affirm good governance, and assure stable working and living conditions. Democracy is an important instrument to mobilize around common goals and to involve the people in nation building and guarantees that the members of the various nations, nationalities, and religions in Ethiopia live in an atmosphere of tolerance. In the absence of a democratic order, national and religious divisions will invariably intensify, the abuse of human rights would result in strife, and poverty would spread further a recipe for disintegration and destruction. The realization of democracy will therefore not only help to attain development and good governance but also ensure national security and survival. Without a doubt, democratization is fundamental to safeguard the individual interests of every Ethiopian as well as to ensure the country's continued existence.

In a nutshell, the nature of domestic political system (which include absence of democracy and good governance) is the major internal determinants Ethiopian foreign policy under the incumbent government which can really determine the style, approach and orientation of the foreign policy of the country because realization of democratic principles and good governance are the bases for perpetual existence of country.

\subsection{Regional and Global Political System}

Ethiopia shares a boundary with all the states of the Horn of Africa which are very difficult to fully monitor and conflict-ridden region. Ethiopia is East by Djibouti, in the south-east by Kenya, in North Eritrea, in the south-west by Somalia in West both by Sudan and South Sudan. Thus, as far as Ethiopia is the land locked found at the nucleus of the Horn of Africa which is the single geostrategic important in the world due to its proximity to Red sea, oil endowed countries and Nile River. The political condition in any of Horn African states have its own impact on Ethiopia, what threatens the national interest of Horn African states today will also threats the national interest of Ethiopian tomorrow [7]. Thus, the presence military base of the other countries such as USA, France, China, Saud Arabia and others in Djibouti determine the foreign policy style, approach, and orientation of the country [9].

Moreover, the incumbent government of Ethiopia also believed that; the development plan and foreign policy objectives of the country will sustainable and realized if there are a shared vision and action for peace and development with all Horn African states. Therefore, this implies that the political dynamism in Horn Africa is the other major determinant factor of Ethiopian foreign policy under incumbent regime because Ethiopia found at the center of Horn African states and this pave the way for horn African states to easily threat Ethiopia. Each of Horn African countries can pose threat to Ethiopia, for instance, Eretria is one headache of Ethiopian security since the outbreak of war in 1998, Ethiopia have almost harmonious relations with all neighbor states except Eritrea till joint is friendship signed between Ethiopia and Eritrean on July 08 2018, failed state Somalia is another security threat to Ethiopia since it is the city of terrorist organization like Al-Shabab, civil war in South Sudan since December 2013 posed the security threat to Ethiopia due to its spillover effects.

The shared resource between and among Ethiopia and Horn African countries and dynamics of Nile hydro politics is the other external determinant of Ethiopian foreign policy under the incumbent government. This determine Ethiopian foreign policy due to the fact the twin objective of Ethiopian foreign policy under the current regime can be realized only by extracting and using Ethiopia's natural resource especially the Nile which is a potential resource that generates hydroelectric power but this potential resource shared by Horn African states and Egypt and again utilization of this resource all require the consent of these riparian states though Ethiopia contributed $86 \%$ of blue Nile and this shared resource determine Ethiopian foreign policy under the incumbent government [12].

The emergence of international issues like terrorism and environmental problem which concern internal community 
and all nation states also pose threat to Ethiopia. The emergence of terrorism alarmed all nation states across the world to redefine and reinterpret their foreign policy specially to curb this global security threat. September $9 / 11$ attack of pentagon and world trade center by terrorist organization rejuvenate Ethio-USA security relation and it turned the eye of USA to Ethiopia as the natural security ally and security partner and it also forced Ethiopia to adopt the counterterrorism Law in 2009 and redefine its own foreign policy so as to avert this global crime and again following the 9/11 attacks against the United States, the Horn of Africa has come under increased study as a strategic focal point in the war against terrorism and other violence [23]. Environmental problem which is also the concern of all nation states in the world can also pose threat to national interest of Ethiopia. Thus, as far the environmental problem is a trans-boundary problem which knocks the door of all nation states, mitigating this problem also requires the effort of all nation states in which Ethiopia is also a partner. Therefore, the emergence of the environmental problem which concerns all nation state and serious threat to the continual survival of the world nation state is the other factor which concern Ethiopian foreign policy under the incumbent government. The rise of non-western powers such as China, India, Brazil, Turkey as an alternative allay and development paths of Ethiopia determine the approach, orientation and style of Ethiopian foreign policy under EPRDF government. In addition to western powers, $21^{\text {st }}$ century manifest the rise new Asian emerging economies, the emergence of Beijing consensus, New Delhi consensus, and South- South cooperation to replace Washington consensus as alternative allay and development model for Ethiopia determine the foreign policy of Ethiopia under the incumbent government [8].

Generally, though Ethiopia's national interest was redefined, and much emphasis was given to internal vulnerabilities like underdevelopment and lack of good governance, dynamics of politics at international level and emergence of trans-boundary problems like terrorism, environmental problem and rise of nonwestern powers as alternative development archetype for Ethiopia are the main external determinants of Ethiopian foreign policy under EPRDF regime.

\section{Conclusion}

Change of regime in a given which takes place either peacefully (democratic election) or forcefully (coup d'état) lead to change in the foreign policy and foreign relations of given states though there are also continuities especially with regard to the objective of foreign policy. The logic applies for Ethiopian foreign policy and foreign relation under military and EPRDF regime. This study found that under military regime Ethiopian foreign policy rigid and reactive and foreign policy approach of the country was also out-ward looking which is all about externalizing all problem ( siege mentality approach). However, the downfall of military regime not merely bring the diversifications of area of foreign policy but also lead to shift of Ethiopian foreign policy approach from out-ward looking approach to in- ward looking approach, from rigid and reactive foreign policy to proactive and somehow flexible foreign policy under the EPRDF government.

Additionally, the finding of the study revealed that the demise of the military regime brought shift in the area of foreign policy from military based to economic based (foreign direct investment attraction, export lead industrialization). Furthermore, the finding of the study uncovered that, domestic, regional and global political system remains the determinants of Ethiopian foreign policy style, orientation and approach both during military and EPRDF regimes.

Finally, the finding of the study revealed that though, the change Ethiopian regime from the military to EPRDF brought a shift in foreign policy approach, style, partners and area of engagements, the objectives foreign policy the country is the same and there are continuities in terms core values and objectives of the countries' foreign policy.

\section{References}

[1] Ahmed, M. (2016). Determinants of foreign policy formulation in developing countries: A case of Kenya. International Academic Journal of Arts and Humanities, 1 (1), 1-53.

[2] Amare T. (1989). The determinants of the foreign policy of Revolutionary Ethiopia. Journal of modern African studies $3(479-502)$

[3] Bahru Z. (2002). A History of Modern Ethiopia 1855-1991 Second edition.

[4] Belachew G. (n.d). The Ethiopian Dilemma between State Security and Human Security.

[5] Berouk M. (2012). Ethiopia's Role and Foreign Policy in the Horn of Africa. International Journal of Ethiopian Studies, Vol. 6, No. 1/2 (2012), pp. 87-113.

[6] Broich T. (2017). USA and Soviet Foreign Aid during the Cold War:A Case Study of Ethiopia.

[7] Chauhan K. (2016). Major Determinants of Bangladesh Foreign Policy, Shrinkhla Vaicharik Patrika Vol. 4.

[8] Elsje F. (2011). Ethiopia and the Search for Alternative Exemplars of Development. An Emerging Post-Washington Consensus.

[9] Gashaw A. and Zelalem M. (2016). The Advent of Competing Foreign Powers in the Geostrategic Horn of Africa: Analysis of Opportunity and Security Risk for Ethiopia. International Relations and Diplomacy. 4 (12) 787-800.

[10] Gedion A. (2011). The USA Military Involvement in Counter Terrorism InThe Horn of Africa. Addis Ababa University unpublished thesis.

[11] Government Communication Affairs Office (GCAO). (2012). Ethiopia's Foreign Policy and its Achievements.

[12] Jan Záhořik (2014) Ethiopia's Hegemony in the Horn of Africa: Internal Tensions and External Challenges Before and After Meles Zenawi. The Journal of the Middle East and Africa. 
[13] Keller E. (1987). Politics of state survival; continuity and change in Ethiopian foreign policy, analysis of American Academy of political and social science vol.489(76-87).

[14] Keller E. (2005). Making and Remaking state and Nation in Ethiopia.

[15] Li Y. (2008). Domestic vs. International Determinants of Foreign Policy: An Empirical Investigation of The Case Of China-Taiwan, 1991-2000.

[16] Mekuriyaw. (2016). United States Policy towards the Hornof Africa since 1991. Inter. J. Polit. Sci. Develop. 4(4): 134-139.

[17] Mehari T. (2014). Ethiopia's Regional Diplomacies. A Dominant Interpretation of the Horn of Africa.

[18] Ministry of Information Press \& Audiovisual Department. (2002). Foreign Affairs and National Security Policy and Strategy.

[19] Muzeyen H. (2015). Ethiopia And The Rising Powers: A Case Study on The Post-Cold War Era Ethio-Turkish Relation, Journal of The Academic Elegance, vol.2.
[20] Schraeder P.(1992). "The Horn of Africa: US Foreign Policy in an Altered Cold War Environment Middle East Journal, Vol. 46, No. 4PP. 571-593.

[21] Seifuddin A. (1997). Islam, Christianity and Ethiopian Foreign policy. Journal of Muslim minority Affairs vol. 17(129-139).

[22] Tedros A. (2015). Ethiopia's Foreign policy: Regional integration and international priorities, Chatham house, the royal institutes of international affairs.

[23] Temesgen G. (2013). "Peasants, land reform and property right in Ethiopia: The experience of Gojjam Province, 1974 to 1997. Journal of African Studies and Development. 5(6), pp. 145-156.

[24] Van der Beken C. (2007). Ethiopia from centralized monarch to the Federal Republic. Africa Focus vol. 20(13-48). 